\title{
Assessment of Temporary Community-Based Health Care Facilities During Arbaeenia Mass Gathering at Karbala, Iraq: Cross-Sectional Survey Study
}

Faris Lami ${ }^{1}$, MBChB, PhD, FFPH; Inam Hameed ${ }^{2}$, MBChB, DFE; Ali Arbaji ${ }^{3}$, MD

\footnotetext{
${ }^{1}$ Department of Community and Family Medicine, College of Medicine, University of Baghdad, Baghdad, Iraq

${ }^{2}$ Karbala Directorate of Health, Iraq Ministry of Health, Karbala, Iraq

${ }^{3}$ Private Practitioner, Amman, Jordan
}

\section{Corresponding Author:}

Faris Lami, MBChB, PhD, FFPH

Department of Community and family Medicine

College of Medicine

University of Baghdad

Bab Al Muadham, Rusafa

Baghdad, 00964

Iraq

Phone: $964+9647901402692$

Email: farislami@yahoo.com

\section{Abstract}

Background: Arbaeenia mass gathering (MG) in Karbala, Iraq, is becoming one of the largest MGs in the world. The health care infrastructure in Iraq is inadequately prepared to serve the health needs of the millions of pilgrims.

Objective: This study aimed to describe the temporary health care facilities installed and run by the local community to provide health care services to Arbaeenia pilgrims in Karbala, Iraq.

Methods: A survey was conducted in all community-based health care facilities located along part of Najaf to Karbala road within Karbala governorate. A structured questionnaire was answered through an interview with the workers and direct observation. Data were collected on staff profile, type of services provided, use of basic infection control measures, medical equipment, drugs and supplies, and the most commonly encountered medical problems.

Results: The total number of health care facilities was 120 , staffed by 659 workers. Only $18(15.0 \%$, 18/120) facilities were licensed, and $44.1 \%$ (53/120) of the workers were health professionals. The health care workers provided different services including dispensing drugs (370/1692, 21.87\%), measuring blood pressure and blood sugar (350/1692, 20.69\%), and caring for wounds and injuries $(319 / 1692,18.85 \%)$. Around $97 \%$ (116/120) health facilities provided services for musculoskeletal disorders and only $16.7 \%$ (20/120) provided services for injuries. The drugs available in the clinic were analgesics, drugs for gastrointestinal and respiratory diseases, and antibiotics, with an availability range of $13.3 \%$ to $100.0 \%$. Infection control practices for individual protection, environmental sanitation, and medical waste disposal were available in a range of $18.1 \%$ to $100.0 \%$.

Conclusions: Community-based health care facilities experienced a profound shortage of trained human resources and medical supplies. They can significantly contribute to health services if they are adequately equipped and follow standardized operation procedures.

(JMIR Public Health Surveill 2019;5(4):e10905) doi: 10.2196/10905

\section{KEYWORDS}

Arbaeenia mass gathering; community-based health care; Iraq 


\section{Introduction}

\section{Background}

Mass gathering (MG) is the assembly of a large organized or unorganized population in a limited space for a specified period, which often strains available resources and services [1]. The World Health Organization (WHO) also defines MGs as "events attended by a sufficient number of people to strain the planning and response resources of a community, state or nation" [2]. The purpose of the assembly is often for a religious, sport, or social event.

MGs occur frequently around the world and pose a whole spectrum of challenges on local country systems. The public health systems can be compromised during MGs if not well prepared even in countries with appropriate resources to prevent and control endemic diseases [3]. Regardless of the type of MGs, various health problems were reported among MG participants and local communities who are at risk of acquiring infectious diseases or injuries [4-8]. Proper planning before the event can help to prevent causalities and health problems. Countries with abundant resources often develop disaster preparedness plans to address MGs; however, many developing countries cannot afford to allocate adequate resources for such events and may seek assistance from other countries [9].

The provision of basic health care and emergency services is essential for the safety of MG attendees. In Iraq, the task of providing these services is under the authority of the Ministry of Health $(\mathrm{MOH})$.

In Iraq, millions of people gather annually on the 20th day of the lunar month of Safar in Karbala for the remembrance of Arbaeen of Imam Hussain from different countries, mainly from Iran, Afghanistan, Pakistan, and Arab Gulf countries, in addition to several millions of people from most provinces of Iraq walking for hundreds of kilometers en route to Karbala (Karbala is located $100 \mathrm{~km}$ southeast of the capital, Baghdad, with a population of approximately 1.2 million inhabitants) over many days that make them at risk of airborne, foodborne, and waterborne diseases and injuries. The Arbaeenia MG is expected to increase in size once the political and security situation of the country stabilizes, as the operation department at $\mathrm{MOH}$ declared that the density of participants increased during previous years. The country's capacity to support the health needs of the MG participants is a concern as the health care infrastructure in Iraq has been negatively impacted by ongoing wars and sanctions affecting the country since the 1990s. Health care facilities have been destroyed during violent conflict, some of which have been rebuilt. In addition, Iraq has lost approximately $50 \%$ of its workforce of physicians since 1990. There were 34,000 physicians registered in the Iraqi Medical Association in 1990, and only 16,000 physicians were registered in 2008 [10]. The local health care infrastructure in Karbala struggles to meet the needs of the local community and is ill-prepared to serve the health needs of the millions of participants in the Arbaeenia MG. Information on the public health in MGs is needed to support the government in planning for Arbaeenia; however, there have been few formal studies conducted on MGs in Iraq [11]. Adequate preparedness plans are essential for handling medical emergencies during the Arbaeenia MG to prevent causalities and harm to population health.

\section{Objectives}

This study aimed to describe the temporary health care facilities installed and run by the local community and provide health care services to the Arbaeenia MG attendees in Karbala, Iraq, as a first step for mapping available resources.

\section{Methods}

A cross-sectional survey was conducted from December 5, 2014, to December 14, 2014, to describe the health care services provided by the local community to participants in the Arbaeenia MG in Karbala, Iraq. Najaf and Karbala are neighboring governorates, and the distance between Najaf City (capital of Najaf governorate) and Karbala city (capital of Karbala governorate) is $80 \mathrm{~km} ; 22 \mathrm{~km}$ are within the boundaries of Karbala governorate. All community-based health care facilities located along these $22 \mathrm{~km}$ within Karbala boundaries were chosen in this study. These health care facilities belonged to civil society organizations called Mawakeb Committees. They offered participants voluntary free-of-charge services such as food and bed as well as basic primary health care services. These facilities were visited and examined after the consent was obtained as part of the study.

\section{Data Collection Tool}

A structured questionnaire was used to collect information on the facilities, staff profile, type of services provided, and inventory of medical equipment and supplies. Data were collected by 5 trained data collectors, and information was collected through interviews with the health workers and observations. The questionnaire was pilot tested before the study was implemented.

Through the questionnaire and observation, information was collected on the health care facilities including licensure status given by the $\mathrm{MOH}$, type of building, type of service offered (dispensing medicine, dressing and suturing wounds and injuries, blood pressure and blood sugar measurements, minor operations, and others), documentation and access to ambulance and mobile clinic services, and availability of clean running water.

In addition, the availability and expiration dates of drugs were recorded. Information on the number of doses and duration of antibiotics dispensed was collected, and their expiration dates were verified. Data collectors also obtained information on the health care facility staff, including age, gender, education, and occupation. Health care workers were asked to indicate the type of medical services they offered to the MG participants. Health care workers were also asked if the facility provided services to MG participants on 4 commonly expected illnesses: respiratory diseases, chronic diseases, injuries, and musculoskeletal disorders.

Information was collected on infection control measures and if these measures were used on all event days, including medical waste management; personal protection measures such as washing hands with soap or using alcohol and wearing 
disposable gloves, face masks, and goggles; and environmental sanitation. An inventory of medical equipment was also conducted.

\section{Statistical Analysis}

The data were entered and analyzed in Epi Info 7 developed by US Centers for Diseases Control and Prevention, Atlanta, Georgia. We estimated the mean age and average score of medical services, drugs, infection control measures, medical services, and medical equipment, in addition to the percentage distribution of health care facility attributes, primary health care services offered by the facilities, availability of drugs, and the sociodemographics of the health workers. We calculated the distribution of the primary health care services by category of health workers, available drugs, available medical equipment, and infection control materials by licensure status of the health care facility. Fisher exact test was used to compare the percentages. A $P$ value of less than .05 was considered statistically significant.

\section{Results}

There were 120 health care facilities along the $22 \mathrm{~km}$, toward Karbala from Najaf, that were included in the study. Only 18 $(15.0 \%, 18 / 120)$ health care facilities were concrete buildings, whereas the majority $(85.0 \%, 102 / 120)$ were tents or caravans. Moreover, 18 facilities $(15.0 \%, 18 / 120)$ had MOH licenses, and $87(72.5 \%, 87 / 120)$ had an identifiable health care facility signage. Presence of mobile clinic or ambulance services in proximity of the surveyed facilities was found only in less than $40 \%$ of the outlets.

\section{Sociodemographic Characteristics}

A total of 659 health care workers staffed these health care facilities, 164 (24.9\%) for the licensed and 495 (75.1\%) for the unlicensed health care facilities. Of the total health care workers, $293(44.5 \%, 293 / 659)$ were health care professionals. The mean age of the health care workers was 37 years (range: $15-85$ years), $84.9 \%$ were male (560/659), and 52.5\% (349/659) had postsecondary education. Of the 164 health workers staffing the licensed facilities, $101(61.6 \%)$ were health care professionals, compared with $192(38.8 \%)$ professional health care workers in the unlicensed facilities (Table 1).

Table 1. Sociodemographic distribution of health care workers working in community-based health care facilities during Arbaeenia mass gathering in Karbala, Iraq, 2014.

\begin{tabular}{|c|c|c|c|}
\hline \multirow[t]{2}{*}{ Sociodemographic variables } & \multicolumn{2}{|l|}{ Workers at the facilities } & \multirow[t]{2}{*}{ Total $(\mathrm{N}=659), \mathrm{n}(\%)$} \\
\hline & Licensed facility $(\mathrm{N}=164), \mathrm{n}(\%)$ & Unlicensed facility $(\mathrm{N}=495), \mathrm{n}(\%)$ & \\
\hline \multicolumn{4}{|l|}{ Sex } \\
\hline Male & $132(80.5)$ & $428(86.5)$ & $560(85.0)$ \\
\hline Female & $32(19.5)$ & $67(13.5)$ & $99(15.0)$ \\
\hline \multicolumn{4}{|l|}{ Educational level } \\
\hline Illiterate & $3(1.8)$ & $20(4.0)$ & $23(3.5)$ \\
\hline Primary & $4(2.4)$ & $68(13.7)$ & $72(10.9)$ \\
\hline Secondary & 47 (28.7) & $166(33.5)$ & $213(32.3)$ \\
\hline Postsecondary & $110(67.1)$ & $241(48.7)$ & $351(53.3)$ \\
\hline \multicolumn{4}{|l|}{ Occupation } \\
\hline Physician-pharmacist & $8(4.9)$ & $33(6.7)$ & $41(6.2)$ \\
\hline Other health professionals & $93(56.7)$ & $159(32.1)$ & $252(38.2)$ \\
\hline Nonhealth staff & $63(38.4)$ & $303(61.2)$ & $366(55.5)$ \\
\hline
\end{tabular}

\section{Diseases Categories}

Around $97 \%$ of health facilities (116/120) provided services for musculoskeletal disorders, $55.8 \%(67 / 120)$ provided services for gastrointestinal disorders, $23.3 \%$ (28/120) for respiratory disorders, $28.3 \%$ (34/120) for noncommunicable diseases and $16.7 \%(20 / 120)$ for injuries.

\section{Provided Health Services}

Health care workers provided some medical services to the participants of the Arbaeenia MG en route to Karbala (Table 2 ), which included dispensing drugs (21.87, 370/1692\%), dressing and stitching wounds and injuries $(18.85 \%, 319 / 1692)$, measuring blood pressure/blood sugar (20.69\%, 350/1692), and providing injections $(16.67 \%, 282 / 1692)$. The majority of these medical services were provided by paramedical health workers $(\geq 57 \%)$, and $81.3 \%(301 / 371)$ of massaging services were provided by nonhealth care workers (Table 2 ). 
Table 2. Distribution of provided medical services by type of personnel working at the community-based healthcare facilities during Arbaeenia mass gathering in Karbala, Iraq, 2014.

\begin{tabular}{lllll}
\hline Medical services & \multicolumn{2}{l}{$\begin{array}{l}\text { Type of personnel working at community-based healthcare facilities } \\
\text { Physician-pharmacist, } \\
\mathrm{n}(\%)\end{array}$} & $\begin{array}{l}\text { Other health care professionals, } \\
\mathrm{n}(\%)\end{array}$ & $\begin{array}{l}\text { Nonhealth care staff, } \\
\mathrm{n}(\%)\end{array}$ \\
\hline Dispensing drugs & $40(10.8)$ & $212(57.3)$ & $\begin{array}{l}\text { Total responses } \\
(\mathrm{n}=1692), \mathrm{n}(\%)\end{array}$ \\
Dressing or stitching & $30(9.4)$ & $203(63.6)$ & $86(27.0)$ & $370(21.87)$ \\
Measuring blood pressure or blood sugar & $31(8.9)$ & $212(60.6)$ & $107(30.5)$ & $319(18.85)$ \\
Injections & $14(5.0)$ & $197(69.9)$ & $71(25.2)$ & $282(16.67)$ \\
Providing massage & $2(0.5)$ & $68(18.3)$ & $301(81.1)$ & $371(21.92)$ \\
\hline
\end{tabular}

\section{Available Medications}

In terms of drug availability, analgesics, antispasmodic, antidiarrhea, antibiotics, and ointments (antibiotics, antiallergy, and others) were available in more than $90 \%$ of the health care facilities (Table 3). The antihypertensive drugs, oral hypoglycemic medicines, and cough syrups were available in less than $60 \%$ of the health care facilities. None of the drugs were expired. There was a wide disparity between the licensed and unlicensed facilities in the availability of all 10 drugs, $39 \%$ and $6 \%$, respectively. On a scale of $0-10$, the average number of drugs available in the health care facility was $7.3(73 \%)$.

According to the inventory of medical equipment, $72.5 \%$ $(87 / 120)$ of the facilities had a sphygmomanometer, $69.2 \%$ (83/120) had a glucometer, and $63.3 \%$ (76/120) had a stethoscope (Table 3). Less than $45 \%$ of the facilities had the remaining medical equipment: thermometer, tongue depressor, and torch. On a scale of 10, the average number of equipment available in the facility was $5(50 \%)$. The average number varied by the type of facility, $7.4(74 \%, 7.4 / 10)$ for licensed and 4.6 $(46 \%)$ for unlicensed facilities.

Table 3. Types of drugs and medical equipment available at the community-based health care facilities during Arbaeenia mass gathering in Karbala, Iraq, 2014.

\begin{tabular}{|c|c|c|c|}
\hline \multirow[t]{2}{*}{ Drugs and medical equipment } & \multicolumn{2}{|l|}{ Type of facility } & \multirow[t]{2}{*}{ Total $(\mathrm{N}=120), \mathrm{n}(\%)$} \\
\hline & Licensed $(\mathrm{N}=18), \mathrm{n}(\%)$ & Not licensed $(\mathrm{N}=102), \mathrm{n}(\%)$ & \\
\hline \multicolumn{4}{|l|}{ Drugs } \\
\hline Analgesics & $18(100)$ & $102(100.0)$ & $120(100.0)$ \\
\hline Antispasmodics & $18(100)$ & $90(88.2)$ & $108(90.0)$ \\
\hline Antiemetic & $15(83)$ & $79(77.5)$ & $94(78.3)$ \\
\hline Antidiarrheal & $17(94)$ & $91(89.2)$ & $108(90.0)$ \\
\hline Antihypertensive & $12(67)$ & $56(54.9)$ & $68(56.7)$ \\
\hline Oral hypoglycemic & $12(67)$ & $59(57.8)$ & $71(59.2)$ \\
\hline Antibiotics & $16(89)$ & $96(94.1)$ & $112(93.3)$ \\
\hline Ointments & $18(100)$ & $94(92.2)$ & $112(93.3)$ \\
\hline Cough syrup & $14(78)$ & $56(54.9)$ & $70(58.3)$ \\
\hline Oral rehydration salt & $8(44)$ & $8(7.8)$ & $16(13.3)$ \\
\hline \multicolumn{4}{|l|}{ Medical equipment } \\
\hline Stethoscope & $16(89)$ & $60(58.8)$ & $76(63.3)$ \\
\hline Thermometer & $10(56)$ & $43(42.2)$ & $53(44.2)$ \\
\hline Sphygmomanometer & $17(94)$ & $70(68.6)$ & $87(72.5)$ \\
\hline Glucometer & $15(83)$ & $68(66.7)$ & $83(69.2)$ \\
\hline Light source & $11(61)$ & $23(22.6)$ & $34(28.3)$ \\
\hline Tongue depressor & $11(61)$ & $18(17.7)$ & $29(24.2)$ \\
\hline
\end{tabular}

\section{Infection control practices}

Table 4 shows the infection control practices in the health care facilities. Washing hands with soap and using antiseptic materials were practices observed by all facilities (100.0\%, 120/120). Percentage availability and observed differences of the other 9 tracer elements were found to be much higher at licensed facilities and statistically significant, except for using 
disposable gloves and syringes and presence of a surgical set. Apart from facilities that only dispensing drugs, 90.5\% (95/105) of remaining facilities used disposable syringes, $79.0 \%(83 / 105)$ used disposable latex gloves, 44.8\% (47/105) used alcohol swabs for cleaning hands, and $41.9 \%$ (44/105) had surgical sets. The remaining infection control measures-medical waste disposal box, environmental disinfectants, facemask, and medical coat-were practiced in less than $22 \%$ of the facilities (Table 4). Only $5 \%$ of the facilities practiced all the infection control measures, $18 \%$ for the licensed and $2 \%$ for the unlicensed facilities. The average score of the infection control practices was 5.1 on a scale of $10(51 \%), 7.8(78 \%)$ for licensed and 4.6 $(46 \%)$ for unlicensed facilities.

Table 4. Availability of infection control measures at the community-based health care facilities during Arbaeenia mass gathering in Karbala, Iraq, 2014.

\begin{tabular}{|c|c|c|c|c|}
\hline \multirow[t]{2}{*}{ Infection prevention control measures } & \multicolumn{2}{|l|}{ Type of facility ${ }^{\mathrm{a}}$} & \multirow[t]{2}{*}{ Total $(\mathrm{N}=105), \mathrm{n}(\%)$} & \multirow[t]{2}{*}{$P$ value } \\
\hline & Licensed $(\mathrm{N}=17), \mathrm{n}(\%)$ & Not licensed $(\mathrm{N}=88), \mathrm{n}(\%)$ & & \\
\hline Washing hands with soap & $17(100)$ & $88(100)$ & $105(100.0)$ & $>.99$ \\
\hline Alcohol-based hand rub & $17(100)$ & $30(34)$ & $47(44.8)$ & $<.001$ \\
\hline Wear disposable latex gloves & $16(94)$ & $67(76)$ & $83(79.0)$ & .08 \\
\hline Use disposable syringes & $16(94)$ & $79(90)$ & $95(90.5)$ & .49 \\
\hline Safety box-medical waste & $9(53)$ & $10(11)$ & $19(18.1)$ & $<.001$ \\
\hline Receptacle with cover & $13(76)$ & $20(23)$ & $33(31.4)$ & $<.001$ \\
\hline Use environmental disinfectants & $8(47)$ & $8(9)$ & $16(15.2)$ & .001 \\
\hline Use antiseptic materials & $17(100)$ & $88(100)$ & $105(100.0)$ & $>.99$ \\
\hline Presence of a surgical set & $11(65)$ & $33(38)$ & $44(41.9)$ & .03 \\
\hline Wear face masks & $10(59)$ & $9(10)$ & $19(18.1)$ & $<.001$ \\
\hline Wear a medical coat & $12(71)$ & $10(11)$ & $22(21.0)$ & $<.001$ \\
\hline
\end{tabular}

${ }^{\mathrm{a}}$ Clinics that provide only drug dispensing were excluded from the analysis.

\section{Discussion}

\section{Principal Findings}

This study shows that the participants in the Arbaeenia MG had access to some form of health care services through facilities on the route to Karbala. The area covered by the study constituted one-fourth of the distance of the road from Najaf to Karbala, which is considered the main road taken by most of the participants, especially those from southern provinces and who come through the Najaf airport, whereas the remaining three-fourths of the road had a similar distribution to the distance covered by the study. Hence, approximately 460 facilities could be available to serve the 14 million visitors with a facility to population ratio of 1:30,000 [12]. This ratio is below the ratio of primary health care units to population in Iraq (ie, 1:10,000) [13]. Other studies indicate a similar facility-population ratio, that is, 7.4:100,000 [14]. Using a similar assumption as above, the expected number of health care workers available to serve the visits could be approximately 2400 , with a health worker to population ratio of approximately 1:6000. Limiting the total expected health workers to expected health professionals of 1065 , the adjusted health worker to population ratio would be $1: 13,000$. This is comparable with the ratio of professional health workers to population in Iraq, that is, 1:15,000. These estimates show that participants in the MG had similar access to health care workers as the general population. The health care facility to population ratio for the visitors is worse than that offered to the Iraq population [15].
The MG participants received limited medical emergency services from the health workers in the health care facilities, including injury management and dispensing drugs. Only one-tenth of the facilities had all the commonly used drugs for the situation. These drugs treat gastrointestinal, respiratory, and common chronic diseases such as hypertension and diabetes, which are common among the participants in Arbaeenia. Similarly, pain killers, antibiotics, and ointments used for multiple illnesses are needed when addressing the health needs of large masses that are at risk of respiratory infections and musculoskeletal pains because of walking long distances [16]; however, $32 \%$ of those who dispensed drugs were nonhealth care staff (Table 2), and this malpractice was reported in the Middle East countries [17-19], Saudi Arabia [20], and even in developed countries [21-25]. One-third and one-tenth of the Iraq population aged 25 years and older have hypertension and diabetes, respectively, and drugs to control the 2 diseases were available in almost three-fifths of the facilities [15]. Medical equipment for measuring blood pressure and blood sugar was also available in three-fourth of the health care facilities. For handling medical emergencies, only two-fifths of the facilities had access to mobile clinics and ambulance services for transporting patients to appropriate hospitals, which may not be adequate.

The facilities practiced infection control measures for individual protection, environmental sanitation, and disposing medical waste. However, only one-fifth of the facilities practiced all the identified infection control measures to protect individuals and environment and for proper disposal of medical wastes. The 
licensed facilities are relatively better than nonlicensed facilities in this area (Table 4). All facilities should practice all the infection control measures required to control the spread of infections and prevent hazards from the environmental and medical wastes. Medical waste disposal should follow special procedures developed by WHO [3,26]; however, less than one-fifth of the health facilities visited had a safe box for disposing medical wastes, which constituted one-half of the licensed facilities. Overall, there were weak medical waste disposal practices and infection control measures. The health facilities can be fertile grounds for spreading infectious diseases to the participants in the Arbaeenia MG and potentially within the region and at a global level.

MGs require well-planned health care services that are executed effectively, including outpatient care services for minor illnesses, care for medical emergencies, and access to ambulance services and designated hospitals for referrals. The temporary health care services for the MG participants traveling to Karbala were set up by local communities without guidance from the $\mathrm{MOH}$. Thus, facility staffing, supply of drugs and medical equipment, and other necessary materials such as infection control materials were established without necessary compliance with $\mathrm{MOH}$ standards. The risk of mass causalities is high, and the government should develop an assessment and response preparedness plan that engages the temporary health clinics for future MGs to prevent causalities and health risks. As the event occurs every year, medical education for physicians and other paramedics should include management of medical problems related to $\mathrm{MGs}$.

\section{Limitations}

The main limitation is difficulty in conducting the study among $80 \mathrm{~km}$ distances from Najaf to Karbala; therefore, the study was conducted by taking a convenience sample that covered only one-fourth of the distance of the road.

This is the first assessment of community-based health care facilities and resources serving the Arbaeenia MG participants traveling to Karbala. Further assessment of the adequacy, quality, appropriateness, and preparedness to respond to mass causalities is needed.

\section{Acknowledgments}

The authors acknowledge the financial support from the Eastern Mediterranean Public Health Network to conduct this study.

\section{Conflicts of Interest}

None declared.

\section{References}

1. Locoh-Donou S, Guofen Y, Welcher M, Berry T, O'Connor RE, Brady WJ. Mass-gathering medicine: a descriptive analysis of a range of mass-gathering event types. Am J Emerg Med 2013 May;31(5):843-846. [doi: 10.1016/j.ajem.2013.01.016] [Medline: 23453125]

2. World Health Organization. 2008. Communicable Disease Alert and Response for Mass Gatherings: Key Considerations URL: https://www.who.int/csr/Mass gatherings2.pdf [accessed 2019-09-03]

3. World Health Organization. 2015. Public Health For Mass Gatherings: Key Considerations URL: http://apps.who.int/iris/ bitstream/10665/162109/1/ [accessed 2018-12-13]

4. Soomaroo L, Murray V. Disasters at mass gatherings: lessons from history. PLoS Curr 2012 Feb 2;4:RRN1301 [FREE Full text] [doi: 10.1371/currents.RRN1301] [Medline: 22453897]

5. Zumla A, Dar O, Kock R, Muturi M, Ntoumi F, Kaleebu P, et al. Taking forward a 'One Health' approach for turning the tide against the Middle East respiratory syndrome coronavirus and other zoonotic pathogens with epidemic potential. Int J Infect Dis 2016 Jun;47:5-9 [FREE Full text] [doi: 10.1016/j.ijid.2016.06.012] [Medline: 27321961]

6. Memish ZA. Meningococcal disease and travel. Clin Infect Dis 2002 Jan 1;34(1):84-90. [doi: 10.1086/323403] [Medline: 11731951]

7. Wilder-Smith A, Goh KT, Barkham T, Paton NI. Hajj-associated outbreak strain of Neisseria meningitidis serogroup W135: estimates of the attack rate in a defined population and the risk of invasive disease developing in carriers. Clin Infect Dis 2003 Mar 15;36(6):679-683. [doi: 10.1086/367858] [Medline: 12627350 ]

8. Razavi S, Ardakani HZ, Rajai S, Hollisaz M, Sadeghipoor H, Farshad A, et al. Trends in prevalent injuries among Iranian pilgrims in Hajj. Iran J Public Health 2011;40(2):110-115 [FREE Full text] [Medline: 23113080]

9. Thackway S, Churches T, Fizzell J, Muscatello D, Armstrong P. Should cities hosting mass gatherings invest in public health surveillance and planning? Reflections from a decade of mass gatherings in Sydney, Australia. BMC Public Health 2009 Sep 8;9:324 [FREE Full text] [doi: 10.1186/1471-2458-9-324] [Medline: 19735577]

10. International Committee of the Red Cross (ICRC). 2010. Iraq: Putting the Health-care System Back on Its Feet URL: https:/ /www.icrc.org/eng/resources/documents/update/iraq-update-290710.htm [accessed 2018-12-13]

11. Al-Lami F, Al-Fatlawi A, Bloland P, Nawwar A, Jetheer A, Hantoosh H, et al. Pattern of morbidity and mortality in Karbala hospitals during Ashura mass gathering at Karbala, Iraq, 2010. East Mediterr Health J 2013;19(Suppl 2):S13-S18 [FREE Full text] [doi: 10.26719/2013.19.supp2.s13] [Medline: 24673093] 
12. Centers for Disease Control and Prevention (CDC). Surveillance for early detection of disease outbreaks at an outdoor mass gathering--Virginia, 2005. MMWR Morb Mortal Wkly Rep 2006 Jan 27;55(3):71-74 [FREE Full text] [doi: 10.1001/jama.295.10.1115] [Medline: 16437057]

13. The WHO Regional Office for the Eastern Mediterranean. 2014. Iraq: Primary Health Care URL: http://www.emro.who.int/ irq/programmes/primary-health-care.html [accessed 2018-12-13]

14. Morimura N, Katsumi A, Koido Y, Sugimoto K, Fuse A, Asai Y, et al. Analysis of patient load data from the 2002 FIFA World Cup Korea/Japan. Prehosp Disaster Med 2004;19(3):278-284. [doi: 10.1017/s1049023x00001874] [Medline: 15571204]

15. World Health Organization. 2008. Iraq: WHO Statistical Profile URL: http://www.who.int/gho/countries/irq. pdf?ua=1\%5Baccessed [accessed 2019-04-20]

16. Alzahrani AG, Choudhry AJ, Al Mazroa MA, Turkistani AH, Nouman GS, Memish ZA. Pattern of diseases among visitors to Mina health centers during the Hajj season, 1429 H (2008 G). J Infect Public Health 2012 Mar;5(1):22-34 [FREE Full text] [doi: 10.1016/j.jiph.2011.10.003] [Medline: 22341840]

17. Sabry NA, Farid SF, Dawoud DM. Antibiotic dispensing in Egyptian community pharmacies: an observational study. Res Social Adm Pharm 2014;10(1):168-184. [doi: 10.1016/j.sapharm.2013.03.004] [Medline: 23665078]

18. Al-Faham Z, Habboub G, Takriti F. The sale of antibiotics without prescription in pharmacies in Damascus, Syria. J Infect Dev Ctries 2011 May 28;5(5):396-399 [FREE Full text] [doi: 10.3855/jidc.1248] [Medline: 21628818]

19. Abuirmeileh A, Samara S, Alkhodari A, Bahnassi A, Talhouni A, Hayallah AM. Antibiotic dispensing without prescription in Jordanian community pharma-cies: a pharmacist's perspective. Bull Pharm Sci 2014;37:51-63 [FREE Full text]

20. Bin Abdulhak AA, Altannir MA, Almansor MA, Almohaya MS, Onazi AS, Marei MA, et al. Non prescribed sale of antibiotics in Riyadh, Saudi Arabia: a cross sectional study. BMC Public Health 2011 Jul 7;11:538 [FREE Full text] [doi: 10.1186/1471-2458-11-538] [Medline: 21736711]

21. Roque F, Soares S, Breitenfeld L, López-Durán A, Figueiras A, Herdeiro MT. Attitudes of community pharmacists to antibiotic dispensing and microbial resistance: a qualitative study in Portugal. Int J Clin Pharm 2013 Jun;35(3):417-424. [doi: 10.1007/s11096-013-9753-4] [Medline: 23397322]

22. Amábile-Cuevas C. Antibiotic resistance in Mexico: a brief overview of the current status and its causes. J Infect Dev Ctries 2010 Mar 29;4(3):126-131 [FREE Full text] [doi: 10.3855/jidc.427] [Medline: 20351451]

23. Zapata-Cachafeiro M, González-González C, Váquez-Lago JM, López-Vázquez P, López-Durán A, Smyth E, et al. Determinants of antibiotic dispensing without a medical prescription: a cross-sectional study in the north of Spain. $\mathrm{J}$ Antimicrob Chemother 2014 Nov;69(11):3156-3160 [FREE Full text] [doi: 10.1093/jac/dku229] [Medline: 24966275]

24. Plachouras D, Kavatha D, Antoniadou A, Giannitsioti E, Poulakou G, Kanellakopoulou K, et al. Dispensing of antibiotics without prescription in Greece, 2008: another link in the antibiotic resistance chain. Euro Surveill 2010 Feb 18;15(7):19488 [FREE Full text] [doi: $10.2807 /$ ese.15.07.19488-en] [Medline: 20184852]

25. Santa-Ana-Tellez Y, Mantel-Teeuwisse AK, Dreser A, Leufkens HG, Wirtz VJ. Impact of over-the-counter restrictions on antibiotic consumption in Brazil and Mexico. PLoS One 2013;8(10):e75550 [FREE Full text] [doi: 10.1371/journal.pone.0075550] [Medline: 24146761]

26. World Health Organization. Safe Management of Wastes from Health-care Activities. Second Edition. Geneva, Switzerland: World Health Organization; 2014.

\author{
Abbreviations \\ MG: mass gathering \\ MOH: Ministry of Health \\ WHO: World Health Organization
}

Edited by Y Khader, A Crawley; submitted 28.04.18; peer-reviewed by A Khattabi, A Alqahtani; comments to author 11.10.18; revised
version received 05.12.18; accepted 14.12.18; published 04.10.19
Please cite as:
Lami F, Hameed I, Arbaji A
Assessment of Temporary Community-Based Health Care Facilities During Arbaeenia Mass Gathering at Karbala, Iraq: Cross-Sectional
Survey Study
JMIR Public Health Surveill 2019;5(4):e10905
URL: $\underline{\text { https://publichealth.jmir.org/2019/4/e10905 }}$
doi: $\underline{10.2196 / 10905}$
PMID: $\underline{31588911}$


CFaris Hasan Lami, Inam Hameed, Ali Arbaji. Originally published in JMIR Public Health and Surveillance (http://publichealth.jmir.org), 04.10.2019 This is an open-access article distributed under the terms of the Creative Commons Attribution License (https://creativecommons.org/licenses/by/4.0/), which permits unrestricted use, distribution, and reproduction in any medium, provided the original work, first published in JMIR Public Health and Surveillance, is properly cited. The complete bibliographic information, a link to the original publication on http://publichealth.jmir.org, as well as this copyright and license information must be included. 